\title{
Impact of Small Scale Irrigation on Farm Technical Efficiency and Household Income in Amhara Regional State: A Stochastic Approach
}

\author{
Tadele Alamneh Woldegiorgis (MSc.) \\ Lecturer, Department of Economics, Debre Markos university Burie campus, Ethiopia \\ Belay File (PhD) \\ Department of Development Economics, Ethiopian Civil Service University, Addis Ababa, Ethiopia
}

\begin{abstract}
Agriculture is the main stay of Ethiopian population with a significant contribution to GDP. More recently the quest for more enhanced production and productivity has become an urgent issue of importance in the agriculture sector. The use of yield improving technological innovations is paramount importance towards this goal. As the potential to increase production and productivity by bringing more resources in to use is limited, the efficiency in which the farmers use available resources has received the utmost attention. This being the case, in this study effort has been made to assess the impact of small scale irrigation on farm technical efficiency and household income. The study was conducted in Amhara regional state. The survey data was collected from four kebeles in Sekela woreda of west Gojjam administrative zone in the year 2014/15 from 119 households. The data collected considered two groups of farm households, irrigation users and non-user households. Stochastic production frontier function with inefficiency variables had been applied to estimate technical efficiency. The finding of income variables indicate that land, access to irrigation, credit, education, labor, total livestock unit, and ox have significant contribution to household income. Among the input variables land and ox have positive and significant contribution to farm production whereas labor has negative contribution to farm production. The coefficient of land and oxen is 0.9 and 0.28 for irrigation users and 1.56 and 0.46 for irrigation non users respectively indicating greater marginal contribution of input variables when irrigation technology is in place. The inefficiency variables, age square, access to irrigation and land are found to improve farm efficiency while age of the household, gender, and dependency ratio have negative contribution to farm technical efficiency. Distance of the farmer's house from development center and extension participation is not statistically significant. The mean technical efficiency of the whole sample was found to be $71 \%$ indicating that there is a possibility of improving the farm output on average by $29 \%$ if the technical efficiency of less efficient households could perform better to obtain the maximum attainable level of output.
\end{abstract}

Keywords: Technical efficiency, Stochastic production frontier, Sekela woreda, Irrigation user and non-user.

DOI: $10.7176 / \mathrm{DCS} / 11-5-01$

Publication date:May $31^{\text {st }} 2021$

\section{INTRODUCTION}

\subsection{Background}

Ethiopian agriculture is largely small scale, subsistence oriented, and crucially dependent on rainfall. The highlands of Ethiopia, which most of the country's agricultural potential, suffer from massive land degradation due to soil erosion caused by heavy runoff and deforestation and the low productivity of peasant agriculture. These trends, combined with repeated drought over the years, have substantially eroded the productive assets of communities and households. A loss of community assets (e.g. pasture and forest) has in turn led to increasing environmental degradation and it also increased the pressure on farm, leading to declining investment in soil and water conservation practices. More importantly, households have become less capable to cope up shocks because they cannot accumulate saving (e.g. livestock holdings and food stores) (MoFED, 2002).

The country continues to face difficulty in meeting the food consumption needs of its increasing population (Lire, 2005). Farmers in Ethiopia have to work an ever-smaller plot of over worked land to produce their food. The per capita cultivated land for food grain has declined from 0.4 hectare in the early 1960 s to 0.1 hectares in the mid-1990s (Debebe, 2000). Although, the percapita cultivated land is becoming lesser and lesser, the production system is highly dependent on rain fed too and produces once annually that farmers lack production intensification using different irrigation schemes to produce more than once a year and a look towards improving this backward farming practice needs the integrated movement of the government and the people altogether to create sustainable food production.

Being dependent on rain fed agriculture coupled with the erratic nature of rainfall distribution is the major factors blamed for the poor performance of the agricultural sector and main cause of widespread food insecurity in the country (FAO 2008). Though the country has 4.5 million ha of irrigable land, irrigation covers only 0.7 
million ha or about 18 percent of the total irrigable land. The dependence of most of the farmers on rain-fed agriculture has made the country's agricultural economy extremely fragile and vulnerable to the impacts of weather and climatic variability leading to partial or total crop failure, which in turn resulted in food shortages (MoWE,2011).

Therefore, small scale irrigation development is the major intervention areas that has to be given due attention to increase agricultural production in the country that supports the farmers to alleviate poverty and provide sufficient food by strengthening the base for sustainable agriculture and secure food and improvement of human nutrition(FAO, 2003).

\subsection{Statement Of The Problem}

Agricultural productivity and production can be increased either by increasing necessary inputs or by introducing modern agricultural technologies. Given agricultural technologies and input level, agricultural productivity and production can be increased through improvement in efficiency of production. Hence, irrigation is a power full instrument for poverty reduction through direct impact of increasing the yield per se and indirect impact like rural employment, lowering the cost of food items, the feedback and multiplier effect associated with the provision of irrigation infrastructure. Besides this, one can also sense that there is an observable income gap between farmers of irrigation users and non-users.

Although small scale irrigation is assumed to improve the livelihood of farmers in the research area, the income gap between irrigation user households and non user households due to irrigation technology is not well addressed and also it is least known that whether irrigation creates variability in technical efficiency among farmers or not. Therefore, this study analyzes the impact of small scale irrigation on farm technical efficiency and house hold income.

\subsection{Objective Of The Study}

The general objective of this study is to analyze the impact of small scale irrigation on farm technical efficiency and household income and;

The specific objectives are:

- To analyze factors that determines house holds' income

- To compare and analyze the income differentials' of irrigation users and irrigation non user house holds

- To analyze the marginal effects (marginal contribution) of explanatory variables of farm production

- To compare the technical in/efficiency differentials and possibility of increasing technical efficiency potentials of irrigation users and non-user farmers

\section{LITERATURE REVIEW}

According to FAO(2008), Ethiopian irrigated agriculture covers only $3 \%$ of the total national crop production that increases agricultural production by 5\%. Even by the low standard of African countries, its irrigation performance is less than $5 \%$ of its irrigable land. In contrast the three countries in Sub-Saharan Africa with the largest irrigation are Sudan (2.2 million ha), Madagascar (1.00 million ha) and Nigeria (0.9 million ha). In Sudan, 14 percent of the country's cropped land is under irrigation, while in Madagascar, the figure is 32 percent. In contrast, almost all the cropped land in Egypt is under irrigation. For comparison, irrigation in Ethiopia covers 0.7 million ha ( $18 \%$ of the country's cropped land).

The current irrigated land covers only 0.7 million ha of the total potential of 5.3 million in which 3.7 million ha can be developed by surface water and 1.6 million ha can be developed by ground water of the estimated potential land area(AQUASTAT, 2015). These traditional small-scale diversion structures are rudimentary and subject to frequent damage by flood and wastage of water available for irrigation, while modern irrigation started by the commercial irrigated sugar estate established in the early 1950's by the Imperial government of Ethiopia the Dutch company known as HVA- Ethiopia followed by private investors in the middle awash for sugar cane, fruit and cotton production in the early 1960's. Following the 1975 rural land proclamation, the large irrigated farms were placed under the responsibility of the Ministry of State Farms but small scale irrigation was given little attention.

It is quite evident that irrigation development in Ethiopia did not attempt to involve the farming population both in planning and construction phases (Desta, 2004). Modern irrigation by and large bypassed the peasant, and the technology involved and the operation and management of irrigation schemes was entrusted a small technical and managerial elite working for large-scale investors interests in the past and later for state or parastatal enterprises. On the other hand, there is a long tradition among peasant farmers of water management for small-scale irrigation agricultural use. More than 40 percent of the irrigated land in the country is served by traditional small scale irrigation (Desalegn, 1999).

Ethiopia cannot meet its large food deficits through rain-fed agricultural production alone. Cognizant to this fact, the government has taken initiatives towards developing irrigation schemes of various scales. This will 
continue and be further strengthened during the coming years. The maximum area quoted to be currently under irrigation is estimated at about 5 percent of the potential, accounting for merely 3 percent of the country's total food production. Various sources give different estimates of irrigated area, but recent sources indicate that the area equipped for irrigation was nearly 700,000 ha in 2008 which is $18 \%$ of the economic irrigation potential of 3.5 million ha from which $39 \%$ of the irrigated area is in Oromia in central parts of Ethiopia, followed by $24 \%$ in Amhara in the north, $15 \%$ in Afar in the north east and 12\% in SNNP which the remaining 10\% is in the other parts of the country(FAO,2008).

In the short-term, however, the irrigation development program gives emphasis to the development of small-scale irrigation in which capacity building in the study, design and implementation of irrigation projects are the forefront.

\subsection{Irrigation Development In Amhara Region}

Amhara national regional state is one of the largest regions in Ethiopia. It occupies a territory extended within a geographical coordinate between $9^{\circ} 29^{\prime}-14^{\circ} 0 \backslash \mathrm{N}$ latitude and $36^{\circ} 20^{\prime}-40^{\circ} 20^{\prime} \mathrm{E}$ longitude. The total area of the region is estimated to be 170152 square $\mathrm{km}$ with ten administrative zones, 106 rural woredas, 12 urban administrations and 3231 kebeles. The region is endowed with four river basins with net potential area of 0.57 million hectares. Modem small-scale irrigation development in the country as well in the region began after the establishment of the irrigation development department within the MoA at the end of 1984.However, the progress was slow. Moreover; most of the modem schemes were poorly operated, managed and under-capacity. At tradition schemes peasant farmers were utilizing irrigation schemes date back to the last century.

According to the MOA(2005), and Awualachew et al. (2007), Amhara region has 770,000 hectares of irrigation potential. Different development activities have been underway to utilize these resources. Currently, there are 311 irrigation schemes operating in the Amhara region and these irrigation schemes developed covers an irrigated 13 areas which covers of 8468 hectares in which from these total irrigated areas 5,719 hectares is from small scale and 2,751 from medium scale irrigation schemes.

According to Yacob et al ( undated), the region has a total irrigated land of 223593 ha, out of which 5,908 traditional schemes that has the capacity to irrigate a total of 208,928 ha and also it has 311 modern schemes that has the capacity to develop 19669 ha. The total beneficiaries in Amhara region are 334,824 households and 1,930,249 families.

At tradition schemes peasant farmers were utilizing irrigation schemes date back to the last century. Lately in 2003, in the national regional food security program, one of the strategies envisaged was the introduction of small-scale water harvesting systems. As a result there was big attempt to introduce small-scale irrigation and house Hold Water Harvesting Scheme(HHWHS) in all parts of the region. A number of different structures were built all over the region. The number of structures built in the same year outstripped those built before.

To identify and know the size and distribution of the structures in the year 2005, the Bureau of Water Resources Development (BoWRD) undertook an exploratory study on the region's irrigation land and water resources. The region has four major river basins with small tributaries which are part of Abay, Tekeze, and Awash river systems; Danakil depression with a total estimated annual renewable potential of 35 billion meter cube fresh water(CoSAERAR,2002). Lakes act also as sub basin of major river basins. The catchment area of the region that contributes for the renewable potential surface water is more than $134,056 \mathrm{~km}^{2}$

(MoWR, 2003).

An indicative point of the wealth of region's underdeveloped water resource was thought that most of the renewable water resources constitute surface water rather than ground water although the understanding and quantification of the latter is rather limited. As stated in the MoWR 15 years water sector development program, availability of ground water in Ethiopia in hard rock formation shows great variability from location to location, depending on recharge, degree of fracture, permeability, obstacle to water movement, concentration and nature of chemical in water depth of ground water level, the case is true for the region as well(Muluken,2005).

The potential land for large and medium scale irrigation of the region is about 650,000 to 700,000 ha and for small scale irrigation is about 200,000 to 250,000 ha (of which less than $10 \%$ has been developed), indicates that the magnitude of water resources available for development but the region has not yet utilized the resource potential efficiently or insignificant portion of the potential has been used in the region( BCEOM,1999).

\subsubsection{Theoretical measures of technical efficiency}

Farrell (1957) was a famous scholar who introduces the first analyses of efficiency measures after dividing it into two components: technical and allocative/price efficiency. Technical efficiency shows firm's ability to produce a maximum level of output from a given level of inputs, whereas allocative /price efficiency presents the ability of a firm to use inputs in optimal proportions, given their prices and existing technology. The sum of the two yields the level of economic efficiency (overall efficiency).

According to Farrell(1975), technical efficiency can be obtained by using input and output quantity. Accordingly, observation P utilizes two inputs to produce a single output i.e one-output, multi input.SS' is the 
efficient isoquant estimated with an available technique of production. Now point Q on the isoquant represents the efficient reference of observation $\mathrm{P}$. The technical efficiency of production unit operating at $\mathrm{P}$ is commonly measured by the ratio (Farrell, 1975).

$T E=\frac{\mathrm{OQ}}{\mathrm{OP}}$

Technical efficiency value will take a value between zero and one showing the extent of technical in/efficiency of the production unit. As value approaches to one, the firm will approach to technically efficient point. from the above figure point $\mathrm{Q}$ is technically efficient since it lies on the efficient isoquant. If planned expenditure for the firm is shown by the slope of the isocost line AA' (figure 1), then allocative efficiency (PQ') of a Production unit operating at $\mathrm{P}$ is defined as the ratio.

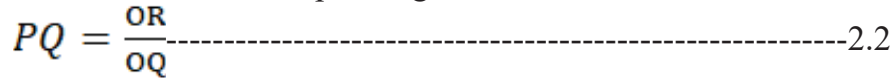

The distance between $\mathrm{R}$ and $\mathrm{Q}$ on the above figure (i.e. RQ) shows reduction in productions costs. This cost reduction would occur when production was to occur at the allocatively and technically efficient point Q' instead of only the technically efficient point $\mathrm{Q}$. The total economic efficiency (EE) is also defined as the ratio (ibid)

$E E=\frac{\mathrm{OR}}{\mathrm{OP}}$

The distance between point $\mathrm{R}$ and $\mathrm{P}$ can also be interpreted in terms of cost reduction. The product of technical efficiency and allocative efficiency s provides the overall economic efficiency.

$E E=T E * A E=\frac{\mathrm{OQ}}{\mathrm{OP}} * \frac{\mathrm{OR}}{\mathrm{OQ}}=\frac{\mathrm{OR}}{\mathrm{Op}}$

Generally, the concept of the production function (or frontier) of Farrell is presented in $\mathrm{x}-\mathrm{y}$ plane axis where the horizontal axis represents the (vector of) inputs $\mathrm{X}$, and the vertical axis represents the resulting output $\mathrm{Y}$ is depicted in the following figure. The observed input-output values are below the production frontier implying firms don't attain the maximum output for the inputs involved, given the technology. Technical efficiency for the firm operating at point A can be measured by taking both the actual observed output and the frontier output associated with the level of inputs, $\mathrm{X}$ (i.e. $\mathrm{Y} / \mathrm{Y}^{*}$ ), where $\mathrm{Y}^{*}$ is the "frontier output". This is an input-specific measure of technical efficiency.

The existence of technical inefficiency of firms engaged in production has been a subject of considerable debate in economics. Some economists argue that given all available inputs to produce certain output for all firms equally, they can produce their output optimally which is identical with frontier output. For example, Muller (1974) states;

"However, little is known about the role of non-physical inputs, especially information or knowledge, which influence the firm's ability to use its available technology set fully .... This suggests how relative and artificial the concept of the frontier itself is.... Once all inputs are taken into account, measured productivity differences should disappear except for random disturbances. In this case the frontier and the average function are identical. They only diverge if significant inputs have been left out in the estimation".

But other economists criticized the aforementioned idea saying that managerial ability of the firm can result in inefficiency in production provided that all required inputs available to them. Upton (1979) was one among such economists who raised basic problems related with empirical production function analysis.

\subsubsection{Empirical studies of technical efficiency on farm-level}

Ethiopian agriculture is dominated by smallholders. Increasing productivity of smallholders is crucial for the country's economic development. There are two schools of thought regarding development strategies for smallscale farmers in developing agriculture. The first one states that there are few inefficiencies that exist in allocation of factors of production in peasant agriculture. The second school of thought states that there exist inefficiencies among small scale farmers. The first, view the problem that to increase productivity, the development and introduction of new technology is required. Whereas, the second school of thought put an emphasis on increasing efficient use of existing technologies and resources which, on the other hand can increase productivity (Farrell, 1957; Schultz, 1964). Several empirical studies conducted at different times in different parts of the world supported this view (Assefa and Franz, 1996; Getu et al., 1998; and Mohammed et al., 2000). Getu et al. (1998) estimated farm specific technical efficiency using survey data collected from sample farmers at Babile, Ethiopia. They used a stochastic production frontier model and the major finding of the study supported the existence of overall technical inefficiency as well as variations in technical efficiency levels among individual farmers. The farm level technical efficiency ranged from $20 \%$ to $91 \%$ in 1993 and from $30 \%$ to $100 \%$ in 1994 , and the mean technical efficiency was found to be $61 \%$ and $69 \%$ in 1993 and 1994 , respectively. Their results imply that the total output of the sample farmers in the study area could have been increased by 30-40 percent above the actual output levels attained.

Mohammed et al. (2000) have reported that the average technical efficiency of barely production in Asasa district of southern Ethiopia is 0.55 , indicating that the farmers are only producing on the average 55 percent of their maximum possible output level, given the state of technology at their disposal. 
Similar studies conducted in developed countries showed technical efficiency variations between farms. In a study aimed at estimating technical efficiency in Swedish crop farms, following a pseudo panel data approach, Heshmati and kumbhakar found that the largest concentration of farms have got the efficiency interval between 75-80 percent. The sample mean of persistent technical efficiency was found to be 76 percent with the standard deviation of 12 percent (Heshmati and kumbhakar, 1997). Tzouvelekas et al. (2001) analyzed the technical efficiency of organic and conventional olive growing farms in Greek and found that the organic olive-growing farms exhibited a higher degree of technical efficiency (relative to their production frontier) than the conventional olive growing farms. There is also a considerable scope for cost reducing and farm income improvement in both farming modes.

Kalirajan and Shand (2001), estimated the technical efficiency of irrigated and non-irrigated farms in Thamil Nadu, India, using stochastic production frontier. They reported that the mean technical efficiency showed increase trend over time for the irrigated sample. From an initial sample average around 68 percent technical efficiency increased season by season with few fluctuations but slowly over 9 years period to around 75 percent giving 7 percent point rise over the period considered. In the non-irrigated sample, the increase over the 9 years was even slower, from 63 to 66 percent, or only 3 percent points for the period. The difference may well reflect the greater production risks in the absence of irrigation and therefore the greater the difficulties for farmers in selecting optimum technical practices.

Desta(2004), conducted a research using the stochastic frontier production function with farm specific production inefficiency variables was used to estimate technical efficiency. The findings indicate that farm size, amount of credit received, education level of household head and access to irrigation have got significant influence on household income. Among the input variables, farm size and capital were found to significantly influence agricultural output, access to irrigation was found to significantly improve the technical efficiency of household. The whole sample mean technical efficiency of irrigation user and irrigation non-user households was $78 \%$. This implies that agricultural output can be increased on the average by 22 percent if technical efficiency of farming households improved to obtain the maximum attainable level of output.

A research conducted by Bekele A. (2013), on technical efficiency variation on small holder farmers irrigated maize production using a stochastic production model to estimate the level of technical efficiency and determinants of inefficiency for maize production. The descriptive statistics of his research found that the mean of maize yield per hectare was 38.4 quintal for non-irrigation user households and 48 quintal for irrigation user households.

The classical test of one-sample mean-comparison test conducted for the production variables used in the estimation of stochastic production function indicates that they are not used at the plot level agronomic standard of the project. The technical efficiency of irrigation user maize producer farmers ranges from $54 \%$ to $98 \%$ with a mean of $91.6 \%$. The study finds that older age of household head, low levels of education for household heads, lack of credit services and limited livestock holding are found to have a positive effect on technical inefficiency

\section{METHODOLOGY}

\subsection{Data Type, Data Source And Data Collection Method}

In this study, both primary and secondary data were employed. A multi-stage random sampling procedure was employed for the selection of sample respondents. Four Kebeles were stratified into two strata: irrigation user and non-user farmers.

\subsection{Method Of Data Analysis}

\subsubsection{Econometric model of data analysis}

It is hypothesized that farmers using irrigation have immediate effect on crop intensity then these farmers who have irrigation schemes have larger productivity and production than farmers that are irrigation non users. Although irrigation users have larger income than non user farmers, income of a farmer is determined by various factors. Therefore, all factors that determine income may not be included because of data availability problems rather some of them were considered in the analysis.

Thus the income analysis of this study was analyzed in the following multiple linear regression technique: $\mathrm{Yi}=\mathrm{B}_{\mathrm{O}}+\mathrm{B}_{1} \mathrm{D}_{1}+\mathrm{B}_{2} \mathrm{X}_{2}+$------ $+\mathrm{B}_{\mathrm{n}} \mathrm{X}_{\mathrm{n}}+\mathrm{U}_{\mathrm{i}-\mathrm{-} \text {-.-- }}$

where, $Y_{i}$ is the annual house hold income of the farmer, $X_{2}, X_{3}, \ldots \ldots, X_{n}$ are the explanatory variables; $\mathrm{D}_{1}=1$ if the house hold has irrigation, 0 otherwise; $\mathrm{B}_{0}$ - is the intercept, $\mathrm{U}_{\mathrm{i}}$ - is the error term.

Economic efficiency can be categorized in to technical efficiency and allocative efficiency. The ability to obtain the highest amount of output with given amount of factor of production is called technical efficiency whereas allocating the resources in the profit maximizing sense is called allocative efficiency. Empirical measurement of the unobservable frontier has two techniques to measure efficiency; those are parametric and non-parametric approaches. The difference between the two lies in the way in which the production possibility frontier is estimated. The non-parametric approach does not require an explicit specification of its functional 
form, however, the parametric frontier does require an explicit specification of its functional form and it is either deterministic or stochastic depending the modeling of the random noise which ignored in the deterministic model but explicitly accounted for the stochastic.

Technical efficiency is determined by the factors such as demographic factors ( age, gender, family size, etc), socioeconomic factors (land holding size, livestock ownership, off-farm income, etc), institutional factors (access to credit, membership of social organization, contact with extension worker, etc), education, geographical distribution, specialization, etc(Brummer, 2001).

The Cobb- Douglas production function was employed to estimate the average production function. The estimated average production function was compared to all observations and deviations from the average production function are a measure of technical inefficiency (Brummer, 2001).

Obviously, random deviations (white noise) can significantly affect the degree of deviation of each observation from the average production frontier and thereby affect the measure of technical efficiency (Brummer and Loy, 2000).

Stochastic frontier production models are designed to overcome the noise problem and it uses a composed error structure with a one-sided component and a two-sided symmetric term. One sided component indicate technical inefficiency effect associated with technical inefficiency of a firm while the two sided component accounts the measurement errors in production and other random effects which are not under management control (Aiger et al, 1977). Therefore, the stochastic production function is specified as:

$\mathrm{Y}=\mathrm{f}(\mathrm{Xi}, \beta) \mathrm{e}^{\phi}$

Where, $\mathrm{Yi}$ is the annual total agricultural output of the household in monetary terms ( in birr); $\mathrm{f}(\mathrm{Xi}, \beta)$ is deterministic part of the production function; $\phi$ represent random error term, $\mathrm{e}^{\phi}$ is stochastic parameter to be estimated. But $\phi$ is decomposed in to two components, because the stochastic frontier model acknowledges that the contribution of random shocks outside the control of the farmer can affect output. Therefore, at least it has to be separated from the contribution of the technical inefficiency variations (Kumbhagar, 2000).

$\phi=\mathrm{Vi}+\mathrm{Ui}---------------------------------(3.3)$,

Where; $V_{i}$ is symmetric error term accountable for random variation in output due to factors outside the control of the farmer, whereas $U_{i}$ represent technical inefficiency related to stochastic frontier assumed to be positive.

The distribution of the symmetric error component $\mathrm{V}$ is assumed to be independently and identically as $\mathrm{N}(0$, $\sigma^{2} \mathrm{v}$ ). The normal error term provides the production frontier to be stochastic and, hence, allows the frontier to vary across or over time for the same producer. However, the distribution of the one sided component $U$ is to be half- normal. That is it assumed to be identical and independently distributed as $\mathrm{N}^{+}\left(0, \sigma^{2} \mathrm{U}\right)$ and it follows that: $\sigma^{2}=\sigma^{2} \mathrm{v}+\sigma^{2} \mathrm{u}$ (3.4)

Considering that $\mathrm{f}(\mathrm{Xi}, \mathrm{B})$ takes the log-linear Cobb-Douglas form, then the stochastic production frontier model in equation (4) could be rewritten as follows:

$\ln \mathrm{Y}=\ln \mathrm{f}\left(\mathrm{X}_{\mathrm{i}}, \beta\right)+\mathrm{V}_{\mathrm{i}}-\mathrm{U}_{\mathrm{i}}$

Taking the natural logarithm of the already specified Cobb- Douglas production function, we can reach the following linear production function which is easily estimable:

$$
\ln \mathrm{Yi}=\beta o+\sum_{j=1}^{n} \beta \mathrm{j} \ln \mathrm{Xji}+\mathrm{Vi}-\mathrm{U}
$$

where, $\ln$ is the natural logarithm and $\mathrm{j}=1,2,3, \ldots \ldots ., \mathrm{n}$; Yi- is amount of output of the household in monetary terms ( in birr); X,s are independent variables (deterministic variables); $\beta$ 's are vector of parameter to be estimated; $\mathrm{V}_{\mathrm{i}}$ represents factors outside the control of the farmer; $\mathrm{Ui}$ is the non-negative random variable which are $\mathrm{U}_{\mathrm{i}} \sim \mathrm{N}^{+}\left(0, \sigma_{\mathrm{u}}{ }^{2}\right)$ reflecting the technical efficiency relative to the production function. But the objective of the study is not simply knowing the inefficiency of productivity variability among farmers of irrigation and non irrigation users in Sekela Woreda rather exploration of the determinant factors which are the sources of technical inefficiencies of the farmer and farm specific attributes. Thus, the second stage was identifying the farm and farm specific attributes that have impact on farmers technical efficiency variation, The inefficiency function can be written as;

$$
\mathrm{U}_{\mathrm{i}}=\sigma_{\mathrm{o}}+\sum_{j=1}^{n} \sigma \mathrm{jZj}+\epsilon \mathrm{i}
$$

where, $\mathrm{U}_{\mathrm{i}}$ is inefficiency scores for the $\mathrm{i}^{\text {th }}$ farmer; $\mathrm{Z}_{\mathrm{i}}$ is variables of inefficiency; $\sigma_{\mathrm{i}}$ is vector of unknown parameters to the inefficiency variables; $\epsilon_{\mathrm{i}}$ the disturbance term included in the model.

Therefore, the final version of the Cobb- Douglas functional form which include both indigenous and exogenous factors to be believed to affect efficiency in the study area will be estimated as ; $\ln \mathrm{Y}=\beta_{\mathrm{o}}+\beta_{1} \operatorname{lnL}+\beta_{2} \ln \mathrm{H}+\beta_{3} \ln \mathrm{OX}+\sigma_{0}+\sigma_{1} \mathrm{AGE}+\sigma_{2} \mathrm{GEN}+\sigma_{3} \mathrm{EDD}+\sigma_{4} \mathrm{DR}+\sigma_{5} \mathrm{~L}+\sigma_{6} \mathrm{IRR}+\sigma_{7} \mathrm{DFP}+\sigma_{8} \mathrm{FAM}$ $+\sigma_{9} \mathrm{EXT}+\epsilon$

where, $Y_{i}$ represents the monetary value of annual total output of a farmer; $\beta 1$ to $\beta 4$ are coefficient of parameter estimates of input variables; L represents total cultivated land holding of the household in hectares; $\mathrm{H}$ is total human labor in man-days utilized; OX represents total oxen power (oxen-days ) utilized; AGE represents 
age of the house hold head; EDD dummy variable representing education level of the house hold having value $=$ 1 if house hold head attends formal education, 0 otherwise; DR represents the ratio of the total number of dependent household numbers to the independent household members (active labor force) of the family; GEN is gender of the household head entered as a dummy variable in the model where the value of 1 is if the household head is male, and 0 otherwise; IRR is a dummy variable having the value 1 if household participate in irrigation, 0 otherwise; DFP represents distance of the plot from the farmer's house in ( km ); FAM is family size of the household; EXT is also a dummy variable having the value 1 if the house hold participate in extension package, 0 otherwise; $\sigma_{1}-\sigma_{9}$ are the coefficient of parameter estimates of inefficiency variables of the model and $\epsilon-$ is disturbance term included in the model.

\section{RESULT AND DISCUSSION}

\subsection{Descriptive Result}

The average family size of the sampled households in the study area is 5.91 persons, with the maximum of 9 and minimum of 2 family size. The number of family members participated in agricultural and off-farm activities ranges from 0.7 to 6.8 person days with the average of 3.51 . Moreover, the mean ratio of inactive labor force to active labor force of the family indicating dependency ratio is $1: 0.77$, implying that there is a relative high dependency in the sampled households. The age of the sampled households ranges from 25 to 80 years of minimum and maximum respectively with mean age of 47.14 years. The total livestock owning is a minimum size of 0 and maximum of 12.1 TLU with average 4.35 TLU and the oxen power is 0 and 4 oxen of minimum and maximum respectively. The land holding of the household varies from 0.25 hectare to 3 hectare with the average being 1.23 hectare of cultivated land per household. The family labor participated in income generating activity is a minimum of 0.7 and 6.8 person-days per household and mean of 3.5 person-days. The mean ratio of a full time agricultural labor to the total land holding was found to be $1: 0.5$ indicating that there is high labor accumulation. The result clearly depicts that there is a relatively high labor disguised employment there in the study area that can diminish labor productivity. This does not consider the occasional supply of inactive labor forces(child and aged persons), which is a usual circumstance to use these labor especially during the peak agricultural times.

Table 1. Households socio economic characteristics and resource endowment

\begin{tabular}{lllllllll}
\hline & \multicolumn{3}{c}{$\begin{array}{l}\text { Irrigation user } \\
\text { households }\end{array}$} & \multicolumn{2}{c}{$\begin{array}{c}\text { Irrigation non-user } \\
\text { households }\end{array}$} & \multicolumn{2}{c}{ Total respondents } \\
\hline & \multicolumn{1}{c}{ mean } & $\mathrm{N}$ & Mean & Minimum & Maximum & Mean & $\begin{array}{l}\text { Std. } \\
\text { Deviation }\end{array}$ \\
\cline { 2 - 9 } Age of HH head & 60 & 45.53 & 62 & 48.89 & 25 & 80 & 47.14 & 11.86 \\
Family size the HH & 60 & 6.03 & 62 & 5.79 & 2 & 9 & 5.91 & 2.01 \\
Labor in the family & 60 & 3.94 & 62 & 3.08 & 0.70 & 6.80 & 3.51 & 1.46 \\
Dependency & 60 & 0.66 & 62 & 0.88 & 0.00 & 4.7 & 0.77 & 0.71 \\
Land in (hectare) & 60 & 1.24 & 62 & 1.22 & 0.25 & 3.00 & 1.23 & 0.57 \\
Live stock(TLU) & 60 & 4.90 & 62 & 3.81 & 0.00 & 12.10 & 4.35 & 2.63 \\
Capital & 60 & 1322.58 & 62 & 933.03 & 0 & 4673 & 1124.61 & 980.2 \\
Ox in oxen-days & 60 & 1.57 & 62 & 1.12 & 0.0 & 4.0 & 1.34 & 1.00 \\
\hline
\end{tabular}

Source: Own survey Data Result (2016)

The irrigation user households ranges from a minimum annual income of 6500 birr to 58644 birr with mean average income of 24395.67 birr while for those households that are not irrigation technology users annual income ranges from 3271 birr to 43417 birr of minimum and maximum respectively and average mean of 13234.65 birr, implying that irrigation has positive contribution to household income. Credit received by irrigation user households and irrigation non user households ranges from 0 to 5000 and 0 to 3500 birr respectively, and the mean credit received is 909.17 and 800.04 for irrigation users and non user households respectively. 
Table 2. Household income, credit received and distance of the HH from dev. center

\begin{tabular}{llllllllc}
\hline & \multicolumn{3}{c}{ Irrigation user households } & \multicolumn{4}{c}{ Irrigation non-user households } \\
\hline & $\mathrm{N}$ & Minimum & Maximum & Mean & $\mathrm{N}$ & Minimum & Maximum & Mean \\
\cline { 2 - 9 } $\begin{array}{l}\text { Income of HH in birr } \\
\text { Distance in kilometers }\end{array}$ & 60 & 0.25 & 58644 & 24395.67 & 62 & 3271 & 43417 & 13234.6 \\
(farmer house to DC) & 15.00 & 3.8717 & 62 & 1.75 & 15 & 3.87 \\
Credit received in birr & 60 & 0 & 5000 & 909.17 & 62 & 0 & 3500 & 800.04
\end{tabular}

Source: own survey data (2016)

From the total respondents $67 \%$ have not taken different credit either in financial or in kind from any source and only $33 \%$ of the respondents get credit finance from different sources. The reason behind is no government organization had given any kind of credit particularly credit in kind for farmers like fertilizer, improved seed, farm implements, etc. From those who get credit, only $26 \%$ of the respondents took credit from Amhara Credit and Saving Institution and less than $1 \%$ of the respondents got credit from local lenders with the amount of money less than 1000 birr because of high interest rate levied on and are not willing to take more money from these local lenders.

Table 3. Sources of credit for households and amount of credit received

\begin{tabular}{|l|l|l|l|}
\hline \multirow{2}{*}{} & \multicolumn{2}{|c|}{$\begin{array}{l}\text { Number of households at a given } \\
\text { source of finance }\end{array}$} & $\begin{array}{l}\text { Neither of the } \\
\text { two } \\
\text { Credit sources }\end{array}$ \\
\cline { 2 - 3 } & ACSI & Local lenders & 82 \\
\hline No credit received households & - & - & \\
\hline Households received credit of below 1000birr & - & 7 & \\
\hline Credit received above 1000 birr & 32 & & \\
\hline
\end{tabular}

Source: Own Survey Data(2016)

\subsection{Econometric Model Results}

\subsubsection{Determinants of household income}

The income of the household is determined by various factors both technically and socially. Besides the descriptions given above, the income analysis was estimated by using the linear regression model. The study has tried to address the objective and give empirical analysis. The preposition that stated there exists no significance income differentials between the irrigation user households and non-user households was tested against the alternative preposition. A multiple linear regression analysis was carried using the software called Statistical Package for Social Scientists (SPSS). The dependent variable considered in the analysis was the total annual household income obtained from both agricultural and non-farm income (off farm) activities. The result is depicted in table 4.

Depending on the model, gender of household head, educational level of the household head, cultivated land size, access to irrigation technology, amount of capital used to purchase agricultural inputs, family labor, livestock ownership, credit availability, oxen power and extension participation are the independent variables assumed to explain the dependent variables. Depending on econometric theories and the data availability, the above variables were believed to influence the income of the farming households. However, it does not mean that the variables included in this model are exhaustive. Moreover, at the initial step the amount of capital used to purchase agricultural inputs were included in the model, but during the time of analysis, the variable was found to have multicollinearity with credit received and total livestock unit. This is because of the major proportion of credit received by the rural households is allocated/ spent to purchase agricultural inputs and the total livestock unit is one of the major source of capital to purchase agricultural inputs that the more livestock unit the household has, the more amount of capital is allocated to purchase agricultural inputs. Hence, the variable was excluded from the model.

The coefficient of the explanatory variables which are educational status, access to irrigation, cultivated land size, family labor, livestock ownership and oxen power have positive sign and significant. However, gender has a negative sign but insignificant and extension participation has positive sign although insignificant. The positive sign of the coefficients indicate that the explanatory variables estimated influenced the dependent variable positively as far as the variables are significant. However, the level of significance differs from one independent variable to the other, but extension participation and gender are insignificant implying that the variables have no contribution to income which is not different from zero. In testing of the hypothesis Ho: $b=0$ against the alternative $\mathrm{H}_{1}$ : b is different from zero; land, access to irrigation credit availability are significant at $1 \%$ confidence interval while education, labor livestock and oxen power are significant at $5 \%$ significance level. Moreover, the coefficient of land, irrigation, ox and education have depicting the significant contributions to household income. 
Table 4. Output of the regression model of income determination

\begin{tabular}{|c|c|c|c|c|c|c|c|c|}
\hline \multirow[t]{2}{*}{ Model } & \multicolumn{2}{|c|}{$\begin{array}{l}\text { Unstandardized } \\
\text { Coefficients }\end{array}$} & \multicolumn{3}{|c|}{$\begin{array}{l}\text { Standardized } \\
\text { Coefficients }\end{array}$} & \multicolumn{2}{|c|}{$\begin{array}{l}95 \% \text { Confidence } \\
\text { Interval of } B\end{array}$} & \multirow[b]{2}{*}{ VIF } \\
\hline & $\mathrm{B}$ & Std Frro & - Beta & t-ratio & $\mathrm{Si \sigma}$ & Lower & Upper & \\
\hline Constant & 3967.308 & 2626.762 & & -1.510 & 0.134 & -9171.900 & 1237.285 & \\
\hline Gender & -893.946 & 1582.933 & -0.023 & -0.565 & 0.573 & -4030.326 & 2242.433 & 1.190 \\
\hline Education & 2298.613 & 1113.297 & 0.084 & $2.065 * *$ & 0.041 & 92.758 & 4504.467 & 1.154 \\
\hline Irrigation & 6463.110 & 1066.979 & 0.264 & $6.057 * * *$ & 0.000 & 4349.028 & 8577.191 & 1.336 \\
\hline Land & 7028.835 & 1259.152 & 0.316 & $5.582 * * *$ & 0.000 & 4533.986 & 9523.683 & 2.245 \\
\hline Labor & 775.223 & 385.913 & 0.090 & $2.009 * *$ & 0.047 & 10.586 & 1539.860 & 1.393 \\
\hline Stock & 819.232 & 381.625 & 0.170 & $2.147 * *$ & 0.034 & 63.091 & 1575.374 & 4.412 \\
\hline Credit & 2.989 & 0.443 & 0.299 & $6.752 * * *$ & 0.000 & 2.112 & 3.867 & 1.372 \\
\hline $\mathrm{Ox}$ & 2020.920 & 907.086 & 0.160 & $2.228 * *$ & 0.028 & 223.646 & 3818.194 & 3.599 \\
\hline Extension & 28.416 & 1200.174 & 0.001 & 0.024 & 0.981 & -2349.574 & & \\
\hline $\mathrm{R}^{2}$ value & & & 0.84 & & & & & 1.448 \\
\hline Adjust. $\mathrm{R}^{2}$ & & & 0.828 & & & & & \\
\hline
\end{tabular}

As indicated in table 5, the coefficient of determination and the adjusted $\mathrm{R}^{2}$ values are 0.84 and 0.83 respectively implying that $83 \%$ of the variation in the dependent variable is explained by the independent variables, indicating relatively high explanatory power of the model.

In testing the hypothesis that $\mathrm{Ho}_{0} \mathrm{~b}_{1}, \mathrm{~b}_{2}, \mathrm{~b}_{3}, \mathrm{~b}_{4}, \mathrm{~b}_{5}, \mathrm{~b}_{6}, \mathrm{~b}_{7}, \mathrm{~b}_{8}, \mathrm{~b}_{9}=0$, against the alternative hypothesis $\mathrm{H}_{1}: \mathrm{b}_{1}$, $\mathrm{b}_{2}, \mathrm{~b}_{3}, \mathrm{~b}_{4}, \mathrm{~b}_{5}, \mathrm{~b}_{6}, \mathrm{~b}_{7}, \mathrm{~b}_{8}, \mathrm{~b}_{9}$ is different from zero, the F statistic was employed and found that $\mathrm{F}_{\mathrm{cal}}=(\mathrm{RSS} /(\mathrm{k}-$ $1)) /((\mathrm{ESS} /(\mathrm{n}-\mathrm{k}))=55.28$ is by far greater than F-tabulated(1.96) and the F value obtained is significantly different from the critical value 9 and 112 degree of freedom for numerator and denominator respectively at significance level of $5 \%$. This can entail that the explanatory variables included in the model jointly influenced total household income and the model output revealed that the null hypothesis is rejected. Hence, the regression result in the study area shows that in rural areas household income is more significantly affected by total cultivated land, credit availability and access to irrigation. The result conforms with the finding of Desta (2004) and Quasam(1994). Education status of the household head, total livestock unit has a positive contribution to household income and this result strengthens the finding of Desta (2004). The amount of family labor and number of oxen utilized in farming activity has also contribution for farmers' income but all these factors have a differential level of contribution to household income. Sex of the household head and extension package participation has no significant contribution to household income.

\subsubsection{Production Frontier and Technical Efficiency Estimates}

The maximum likelihood estimate of the Cob-Douglas stochastic frontier model with the distributional assumption half-normal depicted in table 6 , is evident that the estimates of $\lambda(2.0343)$ and $\sigma(0.73)$ i.e $\sigma=\sqrt{\sigma^{2}}$ $=\sqrt{0.543}$, are large and significantly different from zero, indicating a good fit and the correctness of the specified model and distributional assumption. The observed significance of $\sigma$ at the 5\% significance level suggests that the conventional production function(OLS) is not adequate representation of the data that is the variables have significant contribution to inefficiency and the result is consistent with Tewodros(2001), Hjalmarson et al. (1996), and Sharma et al. (1997). The estimate of $\gamma$, which is the ratio of the variance of farmspecific technical efficiency to the total variance of output is 0.80 . This would mean that about $80 \%$ of the variation in output among farms is due to the differences in technical efficiency and therefore, the stochastic frontier model is different from the OLS indicating there is inefficiency in the production function. The result conforms with Sharma et al. (1997), Hjalmarson et al. (1996), Ali and Flinn(1989).

The input variable total cultivated land of the production function is significant at $1 \%$ confidence interval and have positive sign as of my expectation and parameter coefficient is 0.317 . This result is in conformity with similar studies conducted by Abay and Assefa(1996), Getu et al.(1998), Desta (2004), except the parameter coefficient of this study $(0.317)$ is less than the previous studies.

Oxen power of the production function is significant at $1 \%$ confidence level and positive sign, whereas, the coefficient of labor is significant but negative sign indicating the negative contribution of the input variable to the farm output depicting that the existing farm activity is more focused on light technology utilization such as using of herbicides to remove weeds than using human labor, using of zero tillage by applying chemicals not to plough the farm frequently and remove weeds perhaps it demands high labor force if and when the work is done by human labor. 
In Cob-Douglas production function the parameter estimates measure the elasticity of production which imply that keeping other variables constant, a one percent increase in cultivated land input shall increase a 0.317 percent in agricultural output. Given the current prevailing condition in the study area, the marginal productivity of oxen power, keeping all other factors constant, is the highest followed by cultivated land to increase farm output. The bigger marginal productivity of ox with respect to agricultural output reflects the greater need of oxen power by farmers.

Table 6. MLE production frontier and inefficiency variables of irrigation user and non-user HHs

\begin{tabular}{|c|c|c|c|c|c|}
\hline \multirow[b]{2}{*}{ variables } & \multicolumn{2}{|c|}{ Cob Douglas } & \multicolumn{3}{|c|}{ Translog } \\
\hline & Parameter & ML estimates & OLS estimates & ML & OLS \\
\hline Constant & $\beta_{0}$ & $1.32(8.32)^{* * *}$ & $0.61(2.77)^{* * *}$ & $0.39(0.7)$ & $0.38(1.12)$ \\
\hline Lnlabor & $\beta_{1}$ & $-0.6(-4.3) * * *$ & $-0.54(-3.5) * * *$ & $=\quad-1.09(-2.24) * * *$ & $-1.08(-2.18) * *$ \\
\hline Lnland & $\beta_{2}$ & $0.32(2.96) * * *$ & $0.72(7.26) * * *$ & $2.28(10.1)^{* * *}$ & $2.28(9.8)^{* * *}$ \\
\hline Lnox & $\beta_{3}$ & $1.70(4.46)^{* * *}$ & $0.94(1.96) * * *$ & $0.99(2.4)^{* * *}$ & $0.99(2.34) * *$ \\
\hline$(\text { Lnland })^{2}$ & $\beta_{4}$ & & & $-1.01(-7.3)^{* * *}$ & $-1.01(-7.14)^{* * *}$ \\
\hline$(\text { Lnlabor })^{2}$ & $\beta_{5}$ & & & $0.33(1.77)$ & $0.33(1.73)$ \\
\hline$(\text { Lnox })^{2}$ & $\beta_{6}$ & & & 0 (omitted $)$ & 0 (omitted $)$ \\
\hline \multicolumn{6}{|l|}{ Inefficiency } \\
\hline Intercept & $\sigma_{0}$ & $-4.14(-1.27)$ & & $-11.84(-0.61)$ & \\
\hline Age & $\sigma_{1}$ & $-0.135(-3.32) * * *$ & & $0.26(0.25)$ & \\
\hline Age square & $\sigma_{2}$ & $0.01(4.41) * * *$ & & $-0.004(-0.35)$ & \\
\hline Gender & $\sigma_{3}$ & $5.36(4.23) * * *$ & & $6.15(1.65)$ & \\
\hline Education & $\sigma_{4}$ & $-1.04(-1.84)$ & & $-2.28(-2.44) * * *$ & \\
\hline Irrigation & $\sigma_{5}$ & $1.11(2.23) * *$ & & $0.71(1.19)$ & \\
\hline Family size & $\sigma_{6}$ & $0.16(1.54)$ & & $0.2(1.36)$ & \\
\hline Land & $\sigma_{7}$ & $0.76(2.54) * *$ & & $-3.14(-2.82) * * *$ & \\
\hline Dependency & $\sigma_{8}$ & $-2.15(-3.49) * * *$ & & $-0.15(-0.2)$ & \\
\hline Extension & $\sigma_{9}$ & $1.17(1.09)$ & & $5.13(1.47)$ & \\
\hline Distance & $\sigma_{10}$ & $-0.05(-0.66)$ & & $-0.06(-0.05)$ & \\
\hline Log likelihood & & -56.2204 & & -37.53 & \\
\hline Sigma square & $\sigma^{2}$ & 0.543 & & 0.18 & \\
\hline Gamma & $\gamma$ & $0.80 * *$ & & & \\
\hline Lambda & $\lambda$ & 2.034 & & 0.02 & \\
\hline Mean effi. & & 0.71 & & & \\
\hline Households & & 119 & & 119 & \\
\hline
\end{tabular}

Note: figures in the parenthesis are z-value, T-ratio, and standard errors for ML,OLS and inefficiency variables respectively. ***, **, * indicate significant level at $1 \%, 5 \%$ and $10 \%$ respectively

Although it is less importance for comparison of the level of technical efficiency of the two groups of households, some useful generalizations can be drawn from the model output depicted in table 7 . The table show that the input variables using the maximum likelihood estimation of the Cob-Douglas result of irrigation users and non-user households. The purpose of this decomposition of production frontier in to two categories estimation is that it can show the marginal contribution of each input variable to households of irrigation users and non-users but technical inefficiency is measured in terms of the deviations of farm output from the maximum attainable output that each observation is compared from common reference point. Hence, each farm's output is measured against the fitted regression line. Moreover, the regression line fitted for the two groups of sampled households are different, so that; comparison of inefficiency of households belonging to different group with different regression line or reference point is extremely difficult and misleading. Therefore, the combined result of ML estimation of the technical efficiency for the two groups is presented to indicate how much each group is efficient or inefficient compared to the overall mean technical efficiency value. However, the result of the maximum likelihood estimate input variables using frontier production function analysis for the sampled households of the two groups are presented in Table 7. 
Table-7, Maximum likelihood estimation of the Cob-Douglas production frontier

\begin{tabular}{|c|c|c|c|c|}
\hline \multirow[t]{3}{*}{ Variables } & \multicolumn{4}{|c|}{ Estimated value of } \\
\hline & \multirow[t]{2}{*}{ Parameters } & Irrigation users & \multicolumn{2}{|c|}{ Irrigation non-users } \\
\hline & & ML & ML & \\
\hline Constant & $\beta_{0}$ & $1.95(0.29) * * * \quad 0.75(0.43)$ & $-2.14(-9.3)^{* * *}$ & $0.55(0.16)^{* * *}$ \\
\hline Lnland in hectares & $\beta_{1}$ & $0.9(0.12)^{* * * 0.96(0.16) * * *}$ & $0.28(4.2)^{* * *}$ & $0.08(0.5)^{* * *}$ \\
\hline Lnlabor man-days & $\beta_{2}$ & $-1.05(0.3) * * *-0.67(0.3) * *$ & $-2.35(-2.5)^{* * *}$ & $-0.4(0.12)^{* * *}$ \\
\hline Lnox in oxen-days & $\beta_{3}$ & $1.65(0.4)^{* * *}$ & $0.46(1.74)^{* * *}$ & $1.51(0.5) * * *$ \\
\hline Log likelihood function & & -38.509 & -4.710 & \\
\hline$\sigma=\sqrt{\sigma^{2} u+\sigma^{2}} v$ & & $0.91(0.154)$ & $0.523(0.05)$ & \\
\hline$\gamma=\sigma_{\mathrm{u}}^{2} / \sigma_{\mathrm{u}}^{2}+\sigma_{\mathrm{v}}^{2}$ & & 0.999 & 0.998 & \\
\hline$\lambda=\sigma_{\mathrm{u}} / \sigma_{\mathrm{v}}$ & & 6.33 & 1.55 & \\
\hline Mean efficiency & & 0.76 & 0.66 & \\
\hline Number of households & & 60 & 59 & \\
\hline
\end{tabular}

Note: The figure in parenthesis are standard errors.

$* * *, * *, *$ indicate $1 \%, 5 \%, 10 \%$ significance level

Source: Own computation from survey data (2016)

As shown in table 7, The maximum likelihood estimate of the variables included in the model output depicted that varying degree of relative importance between the two groups. Despite the fact that, the coefficient of land is significant and positive for both irrigation users and non-user households. The estimated coefficient of land was found to be 0.901 and 0.286 for irrigation users and non-user households respectively, indicating a one percent increase in cultivated land increases the income of the household by 0.90 percent and 0.29 percent for irrigation user and non-user households respectively. Therefore, the marginal contribution of land to agricultural output that increases households' income is greater when irrigation technology is in place. The result strengthens the finding of Desta(2004) in Ethiopia, Tewodros(2001) in Nepal China on small holder rice producer farmers.

Moreover, the estimated coefficient of ox was found to be 1.654 and 0.462 for irrigation users and nonusers in their respective order. Furthermore, the estimated coefficient of oxen power is larger for irrigation user households than non-user households implying that the marginal productivity of ox is greater for irrigation than rain fed agriculture. The result conforms with Bekele (2013) and Tewodros(2001). The positive coefficient shows that an increase in the number of oxen-days in the course of land preparation through threshing by one percent will tend to increase income of irrigation user households by 1.654 percent and 0.462 percent for irrigation non-users, keeping all other variables constant in the model. Therefore, it can be observed that the use of irrigation technology has improved the marginal productivity of input variables to agricultural outputs and hence increased the efficient utilization of land and ox.

The variable estimate of labor is significant at $1 \%$ confidence interval level in both irrigation users and nonusers although the negative sign of the parameter is unexpected implying that family labor participated in agricultural activity has negative contribution to farm technical efficiency. This is because, as the size of land is not increasing leading to labor congestion that a larger amount of labor perform relatively lesser amount of agricultural activity but consumption is higher that deteriorates household income leading to labor productivity on agriculture to diminish; and the other reason is perhaps because of the restrictive condition of the CobDouglas specification of the model.

The mean technical efficiency of irrigation users and non-user households is 76 percent and 66 percent respectively. Inefficiency were mainly due to poor farm management and lack of technology. There can be potential for efficiency improvement with in irrigation users and irrigation non-user households. On average the respondents were able to obtain $76 \%$ and $66 \%$ of the potential income from a given mix of inputs for irrigation user and non-user households respectively. This implies also that 24\% irrigation users and 34\% irrigation nonusers farm output was foregone due to technical inefficiency which reflects the inefficient use of the factors of production that were within the control of the farmers. Although there is inefficiency in both groups, we can infer from the model output that the use of irrigation has significant impact on households' farm technical efficiency

Tthe mean efficiency of the respondents was found to be $71 \%$ with a maximum of $99 \%$ and minimum of $14 \%$. This disparity shows either there exists the room for improving the current production performance or achieving the current performance with a lesser input. If we decompose the achievements of technical efficiency by irrigation users and non-user household groups, about $21 \%$ of irrigation users and $65 \%$ of irrigation non-users are operating below the mean technical efficiency. On the other hand, only $35 \%$ of irrigation non-users and $79 \%$ irrigation user are performing above the mean technical efficiency indicating that there exists considerably high technical inefficiency in the non-user households. 
Table 9. Efficiencv score distribution of irrigation user and non-user households

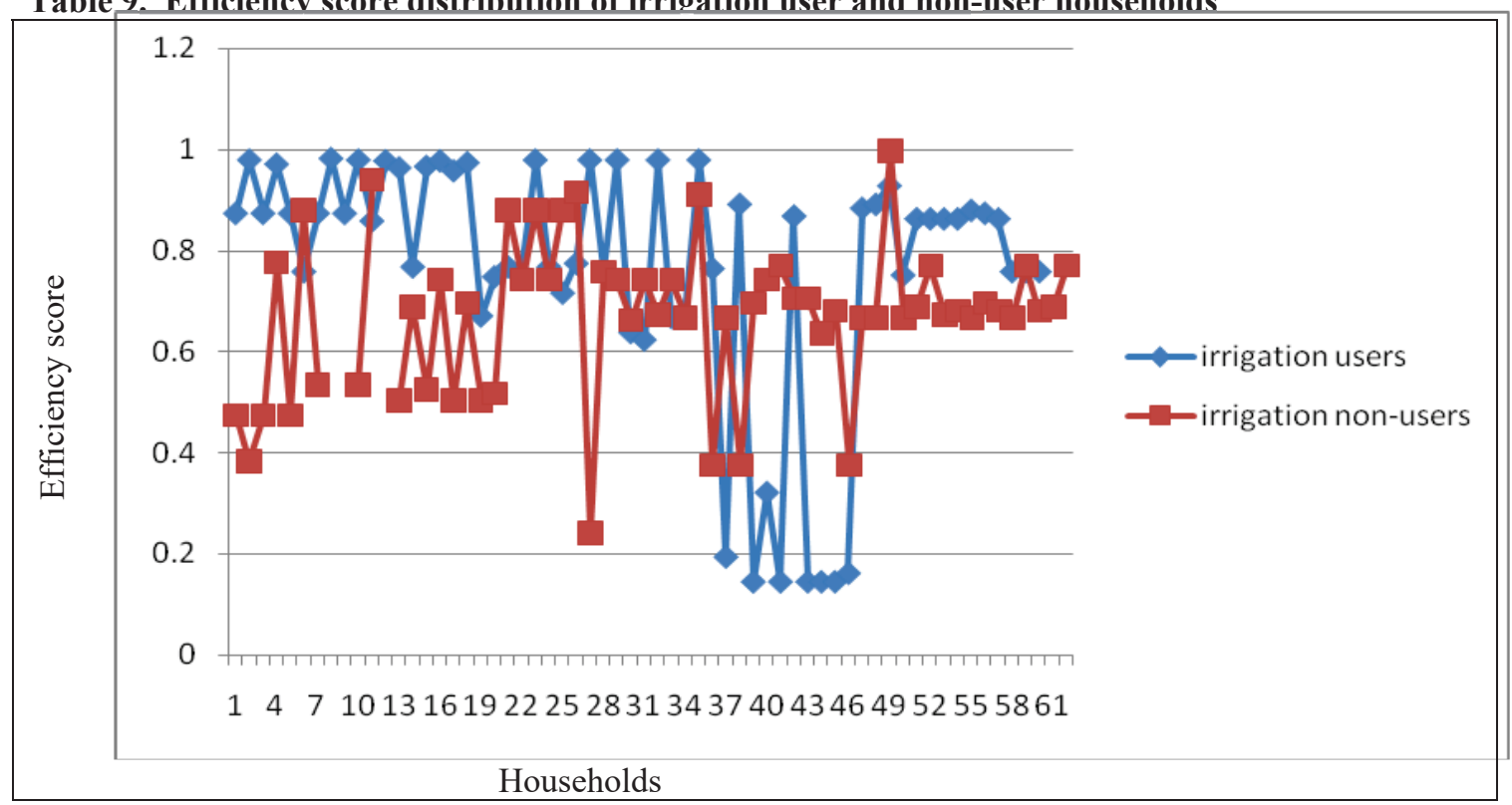

Source: own computation from survey data(2016)

\subsubsection{Sources of Inefficiency Among the Farm and Farm-specific Attributes}

Understanding the sources of technical inefficiency and its extent is very important for policy making to address the problem of farmers. In this regard, demographic, socioeconomic, farm and farmer-specific, and institutional variables were hypothesized to affect level of technical efficiency of irrigation user and non-user households in the study area. Accordingly, the inefficiency model parameter was estimated by using the maximum likelihood estimate of the Cob-Douglas production frontier made on half-normal distributional assumption. The mean efficiency tells us that the level of irrigation user and non-user households output of the sample respondents can be increased if appropriate measure is taken to improve the level of efficiency of the farmers. Nine inefficiency variables were estimated of which six were found to be statistically significant at one percent and five percent significance level with their expected signs. These are age of the household head, age square(a proxy variable of farm experience), gender of the household head, and dependency ratio are significant at $1 \%$ significance level and access to irrigation and cultivated land size of the household are significant at $5 \%$ level of confidence. But other inefficiency variables such as family size, distance and extension participation are insignificant.

\section{i. Age of the household ( $\sigma_{1}$ )}

Age of the household head shows a negative effect on technical efficiency of the farm and significant indicating that an increase in farmer's age by one year reduces the level of technical efficiency by $0.135 \%$. This implies that aged farmers were less technically efficient when compared to their counterparts because it is believed to be reluctant to change their traditional method of production system as age of the farmer increases and the result concurred with the priori hypothesis. This result contradicts with the finding of Kidanemariam(2013), Shumet(2011) and Haileselasie(2005) in Ethiopia, but it is conveyed with the findings of Bekele(2013) in Ethiopia, Bernadette(2011) in Zambia, and Ahmed et al (2002) in Pakistan. However, the impact of age on technical efficiency turned out non-linear which have been captured by the quadratic variable (age square which is a proxy variable for experience). The coefficient of age square was positive and significant at $1 \%$ level. This indicates that technical efficiency first decreased with age up to a certain level beyond which it had positive impact on technical efficiency. This may attributed to the fact that farmers with more years of experience are aged people that have better efficiency because they capture better farm technical efficiency learning-by-doing. Therefore, as age coefficient was negative, experience was positive and this result substantiates the findings of Padilla-Fernandez and Nuthall(2009), and Mohhamed et al (2014). Hence, we can concluded that experience is better predictor of farm technical efficiency than age of the household head.

ii. Gender of the household head $\left(\sigma_{3}\right)$

Gender is included in the model as a dummy variable that it has positive contribution to efficiency and the result shows that being male headed household increase efficiency by $5.36 \%$ and statistically significant. This is because of the fact that, most of agricultural activities like ploughing of the farm, sowing, protecting the farm from flooding, threshing of crops and irrigating their farms when their share of time is at night and protect from destruction by wild animals especially during the night time is unusual farming activities to females (even they don't have a motive to practice) and done by males and these challenges pushed the female households to shareout their land to other farmers leading the female headed efficiency to contribute negatively. The result conforms with the priori hypothesis but contradicts the finding of Tewodros(2001). 


\section{iii. Education level of the household head $\left(\sigma_{4}\right)$}

Education is a dummy variable that is expected to equip farmers with the necessary skill to allocate their scarce resources in optimal way by adopting appropriate technologies that shift their production function outwards. Educated farmers have strong desire to get information and use it than their counterparts. The finding of this variable is statistically insignificant which contradicts the findings of Bekele(2013), Kidanemariam(2013), and Haileselasie(2005). The possible reason for this finding being insignificant was, those farmers who attend formal education are young and lack farming experience that makes them risk averts, and fears their decision to take farm risks, however, farmers that are not attending formal education are mostly aged people. Therefore, aged people(but illiterate) are rich in farming experience that can make the best mix of input variables over the literate farmers. Therefore, the variable education was insignificant. The sign of the variable has no any economic interpretation (which is not different from zero) as far it is insignificant. The result is similar with the findings of Taller and Balbase(1987) that attending formal education has no relationship with efficient use of inputs.

\section{iv. Access to irrigation $\left(\sigma_{5}\right)$}

Households that have access to irrigation technology are expected to have higher farm technical efficiency scores and the result of the model approves this hypothesis. The result shows that if a household have access to irrigation, the technical efficiency of the farm will increase by $1.114 \%$ that leads higher output with a given input variables. This result is also substantiated in the income analysis part of this research ( Table 5) that a one hectare increase in irrigable land of the farmer had had increased the household income by 6463.11 birr annually. Therefore, irrigation has a positive contribution to farm technical efficiency and the model output depicts this fact. The result is in conformity with the findings of Desta(2004).

\section{v. Family size $\left(\sigma_{6}\right)$}

Family size is one important variable for agriculture during the previous times in the study area because it is the major source of family labor. But the model result shows family size is statistically insignificant for contribution of farm efficiency. The result contradicts to the findings of Mbanasor et al (2008), Mohammed et al (2014). The plausible reason for this contradiction result in which family size becomes insignificant was as time gone, the land size of the household share decreases from time to time because of increased population and took a parcel of land and as a result more labor is employed on small plot. Hence, the abundant labor force (especially active labor) had searching for other job opportunities migrating to other regions and engaged on other non-farm activities and the remaining family members left in the family are more of inactive labor force that increases dependency ratio of the household and has lesser contribution to agricultural activities and those family members who are active labor force left in the family are engaged in caring of the children and old ages. Therefore, family size has no contribution to efficiency improvement.

\section{vi. Size of cultivated land $\left(\sigma_{7}\right)$}

Size of cultivated land was found to be positive and significant at $5 \%$ level on technical efficiency. The result indicates that farmers with large farm size are technically efficient because land is the major resource for the farmer and the more the farmer has land, the more the output the farmer would have and the economic capability to purchase more inputs for farm production increase that leads to increase farm efficiency. This finding strengthens the findings of Bravo-Ureta and Pinheiro(1997). However, some studies such as Tchale(2009) and Mohhamed(2014) don't agree with this findings.

vii. Dependency ratio $\left(\sigma_{8}\right)$

Dependency is one of the variables assumed to significantly affect farm technical efficiency of the farmer and found that highly significant at $1 \%$ confidence level and affect efficiency negatively. High dependency ratio with in a family increases the demand for resources for feeding and as the number of dependent with in a family increases, then the demand for basic necessity especially for food, clothing will increase. Hence, the presence of large dependents in the family reduces the amount of family labor and resources available for agricultural production forcing them to allocate more money for their health care, education and more time to care their children and old ages by diverting more resource from production activity to consumption and care of economically inactive people. Therefore, households with high dependency ratio would contribute negatively for efficiency of the farm. This result substantiates the finding of Bekele(2013), Mohhamed(2011), Shumet(2011) in Ethiopia; and Bernadette(2011) in Zambia.

\section{viii. Distance of the farmer's house from development center(in kilometer) $\left(\sigma_{9}\right)$}

Distance is the magnitude of space between the home of the farmer and the development agent's dwelling center in kilometers to get frequent support and practical training on different technological packages on farmer's own farm from the agent. Therefore, households nearer to development agent center are expected to get frequent support on different technologies and practical trainings at the farm level than those who are located at the periphery. But the result is different from the priori expectation because of the reason that practical training on different technologies is given for farmers not on individual farmers plot level rather it is given in centralized form at the farmer training center(FTC) and each farmer is getting the skill based on the schedule set by the consensus of the farmer and the DA(development agent) on the package that the farmer is going to be equipped 
the practical training. Hence, the variable is insignificant and the result is in conformity with the findings of Bekele(2013).

\section{xi. Participation in extension packages $\left(\sigma_{10}\right)$}

Participation in different packages have positive contribution to efficiency of the farm by adopting new technologies and farming practices. Hence, it is expected to affect efficiency positively but the result is insignificant because most of the existing extension packages such as fertilizer application, improved variety seed, compost preparation, pesticide and herbicide application are started before 15 years ago and are old aged and adopted by all farmers with a similar fashion and the new entrant technologies (sowing teff in line ) face failures that most farmers are in dilemma to adopt and participate. Therefore, the variable became insignificant for farm technical efficiency and the result concurs the finding of Desta (2004).

\section{CONCLUSION}

The output of econometric analysis indicated that size of cultivated land, amount of family labor, access to irrigation, total livestock unit, amount of credit received, number of oxen are significant and have positive contribution to household income. Estimation of the production frontier of input variables included in the model indicated that the parameter estimates of cultivated land size and oxen power were found to be significant whereas family labor was found to be significant but the sign of the parameter coefficient is negative. The maximum likelihood estimation of Cob-Douglas stochastic frontier production function coefficient were used to predict the technical efficiency of individual farmers. The mean technical efficiency for the total sample was found to be 71 .

Agricultural output can be increased on average by $29 \%$ with the current level of resource utilization if technical efficiency of the farming households is improved to obtain the maximum attainable output.

Agricultural productivity varies due to differences in production technology, differences in which production occurs and differences in the efficiency of production process. Based on the findings of the study, the following policy implications or concluding remarks can be drawn for further consideration and improvement of irrigation development in the region in particular and in the country at large.

The study revealed that access to irrigation has significant contribution to improve income of the household, implying that countries like Ethiopia affected by climatic variability and recurrent drought, irrigation development is crucial in improving the livelihood of population. specially, small scale irrigation that can increase farm efficiency by producing more than once a year and multiple cropping system that can intensify production has to be center of gravity for the government policy makers to overcome the prevailing challenges that face agricultural output growth over the years. Moreover, the amount of credit was found to be significantly influence household income. This imply that households largely need external financial source but those institutions that offer financial credit are very few. Therefore, to fill the capital deficiency, the recently emerging rural financial institutions should be encouraged and strengthened in terms of number and way of credit delivering modality to reach the needy households.

The frontier output depicts that production frontier input variables affect agricultural output significantly. The land holding and oxen power are highly significant variables to improve the farm households income and attention had to be given to hold the land as productive by applying different technological interventions that can increase production and productivity and changing of the cultural practices and subsistence mode of agricultural practices enhancing labor absorption outside of agriculture because less productivity of land made the labor force out of agriculture and create unemployment in the rural area that created migration to urban areas for seeking of better job and wage but uncertain to get.

The study also highlighted a considerable potential of increasing technical efficiency of the farmers using the current level of agricultural inputs and production technology. Particularly the result suggests that at the given level of fixed and variable inputs level, the output can be increased by $29 \%$ if less efficient farmers were pushed to the level of efficiency achieved by the best farmers. The result clearly showed that there are technical efficiency differences across farmers and, consequently there is a possibility to increase output without major increase in input.

\section{REFERENCE}

Aigner, D., C. Lovell and P. Schmidt.(1977) "Formulation and Estimation of Stochastic Frontier Production Function Models", Journal of Econometrics, 6, 21-37.

Ali M. and Flenni, J. C. (1990) "profit efficiency among Basmati Rice producers in pakistan punjab" American journal of Agricultural economics71: 303-310

AQUASTAT survey. (2005) Irrigation in Africa in figures. Rome, Italy.

Assefa Admassie and H. Franz,( 1996) "Estimation of Technical Efficiency of Smallholders in the Central Highlands of Ethiopia", Ethiopian Journal of Agricultural Economics 1(1): 15-35

Available from: http://waterwiki.net. 
Awulachew SB, Yilma AD., Loulseged M., Loiskandl W.( 2007) Water Resources and Irrigation Development in Ethiopia. Colombo, Sri Lanka: International water management institute

Bakhshoodeh, M. and K. J. Thomson( 2001) "Input and Output Technical Efficiencies of Wheat Production in Kerman, Iran", Agricultural Economics, 24 (3): 307-313.BCEOM and Associates, 1999. Abbay river Basin Integrated Development Master Plan Project.

Bernadette Chewe Chimai (2011) Determinants of Technical Efficiency in Smallholder Sorghum Farming in Zambia: Graduate thesis, School of The Ohio State University BOWR( 2005) Amhara Regional Bureau of Water Resource report [Internet]. [cited 2011 April 8].

Bravo-Ureta, B. E. and A. E. Pinheiro(1993) "Efficiency analysisi of developing countries agriculture" A review of the frontier model, economic Letters 24, 33-38

Brummer, B. ( 2001) "Estimating Confidence Intervals for Technical Efficiency: The case of Private Farms in Slovenia", European Review of Agricultural Economics, 28 (3): 285-306

Brummer, B., J.P. Loy (2000) "The Technical Efficiency Impact of Farm Credit Program: A case Study of North Germany". Journal of Agricultural Economics, 51 (3): 405-418

Chabayanzara, E. (1994) "Smallholder Irrigation Development: Impact on Productivity, Food Production, Income, and Employment", in: Breth, S.A., (eds), African Rural Social Sciences Research Networks, Issues In African Rural Development 2, Winrock International: 185-198

Coelli, T., D.S. Prasada Rao and G. E. Battese,( 1998) An Introduction to Efficiency and Productivity Analysis, Kluwer Academic Publishers, Norwel, Massachusetts, U.S.A

Dessalegn R. (1999) Water Resource Development in Ethiopia: Issues of Sustainability and participation. Forum for Social Studies, Addis Ababa, Ethiopia.

FAO (1995) Irrigation in Africa in Figures. Water Reports. Rome, Italy.

FAO(2015) Maroc, Map of Morroco from the AQUSTAT database, Rome, Italy; United Nations Food and Agriculture Organization /fao.org/nr/water/aqustat/main/index.stm(accessed 19 may 2015).

Farrel, M. J, (1957) "The Measurement of Productive Efficiency". Journal of Royal Statistical Society, Series A, 120: $253-290$

Getu Hailu, V. Bitsch, Belay Kassa, H. Storck,( 1998) "Technical Efficiencies of Smallholder Annual Crop Production in Moisture Stress Areas of Eastern Oromia of Ethiopia: A Stochastic Frontier Analysis". Ethiopian Journal of Agricultural Economics, 2(2): 91-115.

Green, H.W., (2003).Econometric Analysis 5th , Printice Hall, Pearson Education, Inc. Upper

Saddle River, Newjersy. New York University

Heshmati, A., and S. C., Kumbhakar, (1997) " Estimation of Technical Efficiency in Swedish Crop farms: A Pseudo Panel Data Approach", Journal of Agricultural Economics, 48 (1): 22-37

Hjamrson, L. Khumbakhar, S. C. and Hesmati, A(1996)"DEA, DFA, AND SFA: A comparison" Journal of productivtiy analysis 7: 303-327

Kalirajan, K. P., and R.T. Shand, (2001) "Technology and Farm Performance: Paths of Productive Efficiencies Over time", Agricultural Economics, 24 (3): 297-306.

Kidanemariam G.Egziabher Gebrehiwot, 2013, Essays On Income Diversification And Agricultural Extension: A Case from Northern Ethiopia. Doctoral dissertation

Kodde,D.A. and Palm,F.C.,(1986).Wald Criteria for Joint Testing Equality and Inequality Restrictions Econometrica

Kumbhakar, S. C., and C.A. Knox Lovell, (2002) Stochastic Frontier Analysis, Cambridge University press.

MOA (Ministry of Agriculture). (2005) Fogera Woreda Pilot Learning Site Diagnosis and Program Design In: ILRI Fogera PLS planning workshop program; 2004 October 1- 2; Woreta Town

Mohammed Hasssena, F. Hassan, W. Mwangi and Belay, K.( 2000) "Factors Influencing Technical Efficiency of Barely Production in Asasa District of Southern Ethiopia", Ethiopian Journal of Agricultural Economics, 4 (1 and 2): 1-21.

MoWR,(2002) 15 year water sector development program

Onyenwaku, C.E. (1994) " Economics of Irrigation in Crop Production in Nigeria", in: Breth, S.A., (eds), African Rural Social Sciences Research Networks, Issues In African Rural Development 2, Winrock International: 129-138

Paulos Dubale, Michael Menkir, Moltot Zewudie and Lijalem Zeray (2004) Agriculture, Irrigation and Drainage Research in the Past and Future. EARO, Addis Ababa, Ethiopia. http://www.ilri.org/publications/cdrom/integratedwater/iwmi

Quasem, M.A. (1994) "Irrigation and household income, A case study of Bangladesh"; Bangladesh

Sharma, K. R., Leung, P. and Zaleski, H. M. (1997) Productive Efficiency of the swine industry in Hawai: A stochastic frontier vs Data Envelop analysis, Journal of productivity analysis 8: 447-459

Shumba E.M. and R. Maposa.(1996) "An evaluation of the performance of six smallholders irrigation schemes in Zimbabwe", Irrigation and drainage system; 10: 355-366. 
Shumet Assefa (2012) Who is technically efficient in Crop Production in Tigray Region,

Ethiopia? Stochastic Frontier Approach, Global Advanced Research Journal of Agricultural Science.

Taller, L. W. and K. P. Balbase(1987) "short run and long run efficiencies of New York Diary farms" Agricultural and resource economics review 16: 10-16

Tewodros aragie(2001) Farm household technical efficiency: a stochastic frontier approach. A study of rice producers in Mardi watershed in the western development region of Nepal, China.

Thiam, A., B.E. Bravo-Ureta and T.E. Rivas, (2001) "Technical Efficiency in Developing Country Agriculture: A Meta-analysis". Journal of Agricultural Economics, 25: 235-243.

Tzouvelekas, V., C. J. Pantzios and C. Fotopoulos, (2001) " Technical Efficiency of Alternative Farming Systems: The Case of Greek organic and Conventional Olive-growing Farms", Food Policy 26: 549-569.

Yacob W. and melaku T. (n.d) household water harvesting and small scale irrigation schemes in Amhara region, SWHISA project Bahir Dar, Ethiopia. 